\title{
The macroeconomic and environmental determinants of private equity in emerging Asia market: The application of extreme bounds analysis
}

\author{
Isaiah Oino \\ Department of Accounting \& Finance, Greenwich School Of Management, London, UK
}

\section{Email address:}

Isaiah.oino@gsm.org.uk

\section{To cite this article:}

Isaiah Oino. The Macroeconomic and Environmental Determinants of Private Equity in Emerging Asia Market: The Application of Extreme Bounds Analysis. Journal of Investment and Management. Vol. 3, No. 3, 2014, pp. 51-60. doi: 10.11648/j.jim.20140303.12

\begin{abstract}
There is a great debate on the significance of the stable economic and well structure legal system on the commercialization, innovation and employment in modern economies. Private equity activities play a significant role in these three aspects. The purpose of this work is to investigate the macroeconomic and environmental determinants of private equity investment in nine major Asian countries. The estimations are based on a data set running from 2004 to 2013. Applying robust estimation techniques Extreme Bounds Analysis, this work identifies growth in domestic product growth, corporation tax rate, disclosure index and investors' protection index as 'robust' set of determinants of private equity. Also, inflation, stock market value, property right index, legal costs, lending rate and time in days to start business as likely robust. The result suggests the need to enhance business confidence in the country not only through robust monetary and fiscal policy but also legal system.
\end{abstract}

Keywords: Emerging Markets, Private Equity, Venture Capital

\section{Introduction}

Private equity capital is "stable, long-term and high quality that many analysts have noted to add value to firms and economies at large" (Makhene, 2009). At the same time, it compensates investors with the "prospect of earning financial returns fully commensurate with the risks involved". Furthermore, many governments perceive foreign direct investment in the form of robust investment in private equity and venture capital to be an important contributing factor to domestic capital market developments and are making an effort to attract more capital inflow into the country for economic development. In terms of available forms of investment in Emerging Asia markets, as the economy is still under transformation process, the access to investment opportunities is unlimited but limited in terms of capital. Capital is one of the fundamental factors of production that can inhibit the economic growth. Sachs (2001) related growth in per capital income to the importance of primary products in the country's exports. On the other hand Karl (1997) after studying six resource rich countries, the study concluded that resource wealth and resource rent windfall can alter the political climate in the host country. Schertler
(2003) analysed the driving forces of VC activity with data from fourteen Western European countries from 1988 to 2000. This paper showed that the liquidity of stock markets does not affect expansion stage venture capital investments, but affect early stage venture capital investments. Nevertheless, private equity market has been facing several challenges concerning de-equalization of buyouts, conflicts of interest, inadequate regulation and systemic risk to capital markets in economies (Friedman and Grose, 2006).

Despite the challenges, the opportunities in private equity (PE) in emerging markets has developed significantly in the last decade, in both scale and quality, although the magnitude is very small compared with that in developed economies. PE has indeed been a stimulus for economic expansion in developing nations, and this alternative investment asset class should be more widely adopted and encouraged as a vehicle for economic development in developing nations. In order to encourage the capital flow into emerging market private equity, the objective of this paper is to assess the determinants of PE. This would give hints for further development and enhancement of related conditions to attract more investors to inject money into the economy. For those reasons, PE is considered as a suitable investment alternative for this specialised market as the private equity investor 
focuses on the return of their investment in a longer time horizon. However, there is a thin difference between private equity and venture capital (VC). In Europe VC is a specific component of the private equity industry and refers to when funds used to invest in companies especially during startup. In turn, PE applies at a later stage of the company or at maturity. The stage of development of the portfolio company determines the nature of investment to receive. Seed capital is usually used to finance initial product research and development. On the other hand startups investments are offered to companies that have passed the idea stage and are moving into production, marketing and sale stage. Together seed and start-up stages are referred as early stage investments. After early stage, a company enters an expansion stage where the company needs additional capital to finance its growth or expansion. In this, buyouts are usually applied. In PE investments, there are different types of buyouts such as leveraged buyouts and management buyouts. The former is used as to acquire a company and reduce its equity base, whereas the latter is a leveraged buyout where current management takes control of the company. For the purpose of simplicity, in this paper $\mathrm{VC}$ is treated as a segment of PE. The rest of the paper is as follows: section 2 examines the relevant literature; section 3 estimation method; section 4 analysis of the result and discussion and section 5 concludes the findings.

\section{Section 2: Literature Review}

Since PE investments are typically organised into a limited partnership funds, most analysis of returns considers the persistence in performance across the successive funds of a particular PE manager. This creates challenges: funds have lives that are often in excess of ten years. This reflects the time taken to acquire, work with, and exit the portfolio companies in which they invest. The ultimate performance is only known accurately at the point when all investments have been exited and the cash has been returned to investors, but the speed with which funds enter and liquidate their positions varies considerably. Until exit, funds report their estimates of asset values, but these may be biased predictors of future cash returns. In recent years, emerging market share of number and value of PE deals has constantly increased. During the period from 2005 to 2009, total number of PE deals doubled from 12 to $30 \%$ of total deals, while the value tripled from 8 to 21 percent. A number of studies have demonstrated that entrepreneurial performance as PE-backed firms create more innovations, employment and growth than their peers that and a strong PE market is a cornerstone for commercialization and innovation in modern economies (Kortum and Lerner, 2000 and Belk et al 2003).

Notwithstanding the positive impact of PE activity on economic wealth, there exist substantial difference in the relative amounts raised and invested in PE across industrialized as well as developed economies. In particular, countries like the US or the UK feature a strong market for this asset class, while in Japan the level of PE intensity is rather low. As far as Europe is concerned, despite the considerable growth of PE investments over the last decade, the diversities in PE activity across countries are still significant. There now exists a broad consensus variety of factors has led to an impressive development in emerging market.

\subsection{Private Equity in Asia}

The first four core metrics of PE which are fund-raising, deal volumes, deal values, and exits all points to a return of strength for Asian PE. A survey conducted by Ernst and Young (2014) indicated that, $76 \%$ of respondents in Asia had high expectations that PE deal activity in 2014 will increase. Their previous survey indicates insignificant change in that $86 \%$ for the 2013 outlook and $70 \%$ since 2012 — with survey participants noting that volatility in Western markets and Asia-Pacific's abundance of investing opportunities will continue to draw PE dollars.

Another measure, investor nationality, attests to the changing balance of foreign and local investors in Asia. Local players were responsible for 18 percent of all investments by deal value in 2010, down from 29 percent in 2009. Nevertheless, there has been a significant increase of PE activities in Asia compared with other emerging markets as shown below.

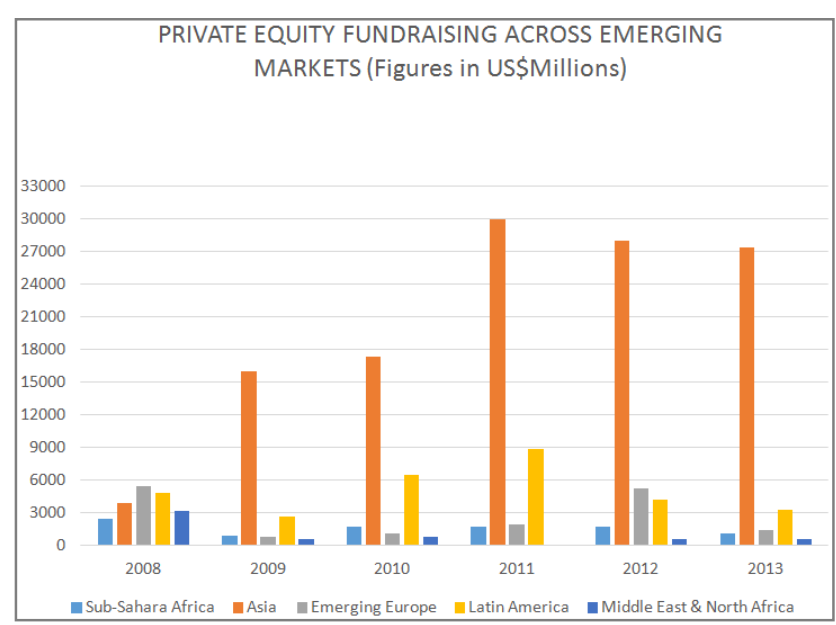

Source: EMPEA (2014), compiled by the author.

Figure 1. Private Equity across Emerging Market.

\subsection{Determinants of Private Equity}

A number of researchers have focused on the determinants of PE markets in both developed and emerging markets. The significance of each determinant is different in each report. In the aspect of emerging market, some recent papers emphasized the benefit of high economic growth rate as well as population growth of emerging markets as the favourite condition for increasing capital flows in emerging PE market (Gompers et al.2008). On the contrary Jeng and Wells (2000) in their panel data of 21 companies over 10 years, showed that GDP growth is not significant in determining PE. Bonini and Alkan (2009) also confirm the positive relationship between risk capital and GDP growth. 
An important step towards the assessment of the competitive position of countries regarding the reception of risk capital funding is made by Groh and Liechtenstein (2009a and 2009b), who performed a survey among institutional investors when allocating $\mathrm{PE}$ in emerging markets. The authors concluded that, protection of property rights and corporate governance are perceived as most important for international PE allocation decisions, followed by the assessment of the management quality of local entrepreneurs according to Western management standards. This is in line with Desai et al (2006), when they investigated the influence of institutional settings of 33 European countries in addressing the issue of fairness as protection of property rights on the entry of entrepreneurs into the market. In addition, Cumming et al (2010) concluded that, the quality of a country's legal system matters more than the country's stock market. Unexpectedly, according to Groh and Liechtenstein (2009a and 2009b), institutional investors in $\mathrm{PE}$ are not impressed by government programs to spur local risk capital markets. The findings indicated that, the availability of public funding plays no role in allocation PE.

On other fronts, several papers show that also gross domestic product (GDP) growth plays a significant role in attracting PE investment. Gompers et al (2008) in unreported regressions, they modelled expected GDP growth using the previous four years of real growth. Instead of lagged GDP growth, they estimated the regressions using the expected growth rate using the data from 1972 to 1994. They concluded that, higher GDP growth implies higher attractive investment opportunities and hence need PE. While Jeng and Wells (2000) did not find a significant effect of GDP growth on venture capital (VC) investment. Bonini and Alkan (2009) also confirmed the positive relationship between risk capital and GDP growth. Gompers et al (2008) and Bonini and Alkan (2009) argued that the level of interest rates in a country might be relevant in attracting VC. One theory is that level of interest rates should have a negative impact on the volume of $\mathrm{PE}$ since higher interest rates reduces the attractiveness of risky investments.

Concerning the impact of capital gains tax rates on $\mathrm{VC}$ activity, Gompers et al (2008) concluded that a decrease in the corporate tax rate has a positive and significant impact on commitment to new VC funds. Similarly, Bruce (2000 and 2002), Cullen and Gordon (2002) and Bonini and Alkan (2009) noted that, taxes affect significantly the entry of businesses. Focussing on European countries, Groh and Lichtenstein (2009) argued in their survey among institutional investors that, low corporate taxes (on average) are the strongest incentive for investors to invest in these emerging markets.

Schertler (2003) used dynamic panel estimations to identify the drivers of VC activity in 14 Western European countries between 1988 and 2000. The study emphasized that, the liquidity of stock markets (proxied by either stock market capitalization or the number of listed firms), human capital endowment (proxied by the number of employees in the R\&D field and the number of patents) and labour market rigidity. The study indicated that, labour market negatively affect PE. This is because institutional investors could hesitate investing in countries with exaggerated labour market protection and immobility.

Kumar and Orleck (2002) used data covering 9 countries in North America and Europe over the period between 1986 and 1999 and a shorter period from 1994 to 1999 to assess the factors that may influence $\mathrm{PE}$ or $\mathrm{VC}$ financing commitments as a percentage of GDP. Using a pooled regression technique they found that the legal environment variable is positively significant. This finding supports the notion that the legal environment influences venture capital activity. Cumming, Schmidt and Walz (2010) used data consisting of 3,848 portfolio companies spanning the period from 1971 to 2003 across 39 countries in North America, Europe and Latin America to assess the influence of the legal environment on venture capital markets. Using Cox proportional hazard, ordered logit, and Heckman two-step regression techniques, they noted that the legal environment is positively and significantly related to faster deal origination.

\section{Section 3: Estimation Method}

In order to make our data set as homogenous, we divide all variables related to the $\mathrm{PE}$ expressed in local currency with observed GDP figures. The rationale is that although the countries in our sample belong to a common economic block, they still differ in their economic activities.

There is no universally accepted theoretical framework to guide empirical work on the choice of the appropriate model. Nevertheless, there are a number of variables that have been suggested in the existing literature to be potential determinants of PE investment. Only a few studies control for the variables analysed by others, and therefore the robustness of the estimation results to the inclusion of additional explanatory variables is questionable. Ideally, one only wants to include regressors that turn out to be robust to the inclusion or omission of other regressors. These researchers attempt to solve the problem of model selection under uncertainty and small data samples by applying a so called 'Extreme-Bounds Analysis' (EBA) proposed by SalaI-Martin (1997), which built on earlier work by Leamer (1983, 1985) and Levine and Renelt (1992). The idea of Salai-Martin's approach is to estimate a large set of model specifications and to check how sensitive the estimated coefficient of each variable is the inclusion of additional explanatory variables. EBA constitutes a relatively neutral way of coping with the problem of selecting variables for an empirical model in a situation where there are conflicting or inconclusive suggestions in the literature. This work employs two methods that have been proposed as appropriate for isolating robust relationships (Leamer1983, Sala -IMartin1997).

Cross-sectional studies of the PE fundraising are usually based on a regression that takes the following form which makes use of panel data methodology. The use of panel data 
helps one control individual heterogeneity between the countries. There are relevant factors like, for example, entrepreneurship or cultural, sociological, environmental one that is different for each country (but constant in time) and can be causing a different effect on the dependent variable. The problem is that these variables are very difficult to measure and the omission of these variables leads to bias in the resulting estimates.

$$
P E_{i}=\beta_{0}+\sum_{K=1}^{N} \beta_{K} X_{k i}+\varepsilon_{i}
$$

Where PE is private equity fundraising into country $i$ and $\mathrm{X}_{\mathrm{ki}}$ denotes the $\mathrm{k}^{\text {th }}$ explanatory variable of country $\mathrm{i}$. Many studies report a sample of regressions, using a certain set of explanatory variables. The problem is some of the variables in some settings are found to be significant while in other studies or setting they are reported insignificant hence difficult to assess the true model as noted above. The main difficulty that usually occurs, according to Sturm and Haan (2002), is that numerous different models may all seem reasonable given the data, but yield different conclusions about the parameters of interest. $X_{1}$ may be significant when the regression includes $\mathrm{X} 2$ and $\mathrm{X} 3$, but not when $\mathrm{X} 4$ is included. So, which combination of all available $\mathrm{X}_{\mathrm{k}}$ 's chosen becomes a generally a guess work by many researchers. In some cases, some studies often restrict their analysis to certain subsets of these variables and often ignore the effects of any omitted variable bias when other variables are not included. Others report the most "appealing" or convenient regression or regressions after an extensive search and data mining and those that possibly confirm a preconceived idea. This negates the essence of a researcher being as objective as possible. The use of EBA reduces the biasness from the researcher by reporting the upper and lower bounds of the variables under investigation.

The random-effects model was used in this research because when some variables are constant for each country, fixed-effects regression is not an effective tool due to that such variables cannot be included (Dougherty, 2007). The panel data of the study are composed of 9 Asian countries over the period 2004 to 2013. The linear regression framework to be applied is as follows:

$$
Y=C+\beta_{I} I+\beta_{M} M+\beta_{Z} Z+\varepsilon
$$

Where $\mathrm{Y}$ is the PE, I is a set of variables always in the regression, $M$ for variables of interest that need to be examined, its fragility or robustness and $Z$ for a set of variables that we choose from a set of variables that identified as a potential determinants of PE.

Using an EBA closely this research follows the approach of the Levine and Renelt (1992) as follows. First, the variables that are being emphasized in previous empirical studies are chosen as determinants of PE and then estimate a

${ }^{1}$ Great China, Japan, India, Singapore, Malaysia, Thailand, Indonesia, Vietnam and Philippines. base regression that includes only the I-variables and the variables of interest. Second, estimate the next regressions including all possible linear combinations of up to three Zvariables to identify the highest and lowest coefficient of the M-variable $\left(\beta_{M}\right)$. The extreme upper is defined as the maximum value of $\beta_{M j}+2 \sigma_{M j}$, the lower bound as the minimum value of $\beta_{M j}-2 \sigma_{M j}$, where $\beta_{M j}$ is the estimated coefficient of M-variable and $2 \sigma_{M j}$, is its standard deviation in jth model. If the extreme upper bound and lower bound have the same sign, then M-variable is referred to be robust, otherwise is fragile.

Sala-I-Martin (1997b) criticized on Levine and Renelt approach and argued that their criteria are very rigid and is really hard for any variable to pass it. He introduced the confidence level to quit giving the label of one or zero to the variables, and considered the whole distribution of the coefficients of the M-variable, $\left(\beta_{M}\right)$. He computed the fraction of cumulative distribution function lying on each side of zero and named the greatest area $\operatorname{CDF}(0)$. He also used the weighted approach to give more importance to the regression that is more likely to be true. He used the goodness of fit of the model as a likelihood of being true. Sala-i-Martin pointed out even though each individual $\beta_{M j}$ follow a $\mathrm{t}$ student distribution, all estimates might be scattered in an unrecognized fashion. Hence, one can operate under two different assumptions.

If the distribution of the estimates of $s$ is normal, one can calculate a cumulative distribution function (CDF) from the mean and the standard deviation of the distribution. The likelihood L for each possible model based on goodness of fit is necessary to calculate the weighted mean $\beta_{M j}$ of and $\sigma_{M}$ as follow:

$$
\begin{gathered}
\hat{\beta}=\sum_{j=1}^{n} w_{j} \beta_{M j} \\
\hat{\sigma}=\sum_{j=1}^{n} w_{j} \sigma_{M j} \\
w_{j}=L_{j} / \sum_{j=1}^{n} L j
\end{gathered}
$$

where $L_{j}$ stands for likelihood of $j$ th regression. If the distribution of the estimates of across all models is not normal, one can compute individual $\operatorname{CDF}(0)$ for each regression, then compute the aggregate $\mathrm{CDF}(0)$ of as the weighted mean of all the individual $\operatorname{CDF}(0)$ that the weights are similar to normal case. Variables that their CDF are larger than 0.95 are said to be robust.

The rule of decision in Sala-i-Martin approach is different. In his procedure, one must consider the distribution of the estimated coefficients. Under normal assumption and by computing $\hat{\beta}$ and $\hat{\sigma}$, one can standardize the distribution of estimated coefficients then based on normal standard distribution table compute $\operatorname{CDF}(0)$. It should be noted that the area under the density function divided into two areas by 
zero, the greater area, regardless of whether it is below or above zero, called CDF (0). Although under non-normal assumption according to that we know each estimated variables have t-student distribution and this distribution tend to be normal distribution if observation number is considerable, and under the assumption that $E\left(\hat{\beta}_{M}\right)=\beta_{M}$ one can standardize estimated coefficients then based on normal standard distribution table compute individual $\mathrm{CDF}(0)$ for each regression, then as we pointed above, compute the aggregate $\operatorname{CDF}(0)$ of as the weighted mean of all the individual $\operatorname{CDF}(0)$. Therefore if aggregate $\operatorname{CDF}(0)>0.95$, variable is significantly and robustly correlated with PE. As Sala-I-Martin (1997b) pointed out if for variable 1, $\operatorname{CDF}(0)=0.95$ and for variable $2, \operatorname{CDF}(0)=0.52$, then variable 1 is more likely to be robustly correlated with PE.

One necessary condition for the panel estimation approach is that the data from these countries are 'poolable' and there is no serial correlation and heteroskedasticity as shown in appendix tables 4 and 5 .

\section{Section 4: Analysis of Result and Discussion}

Whereas Sala-i-Martin regards a variable as a 'robust' determinant, if $90 \%$ of the distribution of the slope coefficient is positive or negative, respectively, this work take a less restrictive threshold of $60 \%$. This choice is motivated by the fact that the data set is relatively small, which in turn will result on a higher uncertainty around the estimated coefficients. Four variables are considered to be robustly related to $\mathrm{PE}$ investment, according to the criterion $\operatorname{CDF}(0)>0: 60$. This is corporation tax, GDP growth, disclosure and investors protection. On the other hand, as per Sala-I-Martin, a total of six variable have $\operatorname{CDF}(0)>0.52$ hence likely to be robust. These are inflation, stock market value, property rights, lending rate, legal cost and time in days to start a business. Nevertheless, it is paramount to compare the PE activities across the emerging markets at the onset

Table 1. Private Equity fundraising across emerging markets (fig in US\$B).

\begin{tabular}{lllllll}
\hline & $\mathbf{2 0 0 8}$ & $\mathbf{2 0 0 9}$ & $\mathbf{2 0 1 0}$ & $\mathbf{2 0 1 1}$ & $\mathbf{2 0 1 2}$ & $\mathbf{2 0 1 3}$ \\
\hline Sub-Sahara Africa & 2425 & 939 & 1690 & 1735 & 1684 & 1134 \\
Asia & 3867 & 15956 & 17310 & 29942 & 28023 & 27404 \\
Emerging Europe & 5444 & 839 & 1095 & 1904 & 5241 & 1383 \\
Latin America & 4874 & 2613 & 6534 & 8890 & 4211 & 3248 \\
$\begin{array}{l}\text { Middle East \& } \\
\text { North Africa }\end{array}$ & 3129 & 637 & 787 & 44 & 575 & 568 \\
\hline
\end{tabular}

Source: EMPEA, 2014. Compiled by author.

Table 2. Private Equity Investment across emerging markets (fig in US\$B).

\begin{tabular}{lllllll}
\hline & $\mathbf{2 0 0 8}$ & $\mathbf{2 0 0 9}$ & $\mathbf{2 0 1 0}$ & $\mathbf{2 0 1 1}$ & $\mathbf{2 0 1 2}$ & $\mathbf{2 0 1 3}$ \\
\hline Sub-Sahara Africa & 2359 & 1015 & 793 & 1492 & 1125 & 1610 \\
Asia & 19934 & 14392 & 15926 & 19315 & 15406 & 17406 \\
Emerging Europe & 5962 & 3713 & 1850 & 3526 & 2299 & 1961 \\
Latin America & 2960 & 2693 & 6613 & 3905 & 5486 & 5246 \\
$\begin{array}{l}\text { Middle East \& } \\
\text { North Africa }\end{array}$ & 1781 & 233 & 736 & 384 & 1596 & 210 \\
\hline
\end{tabular}

Source: EMPEA, 2014. Compiled by author.
As shown in table 1 above, since 2009 Asia has been in the forefront in terms of equity fundraising. At the height of the pre-crisis boom, in 2007, Asia accounted for roughly 10 percent of global private equity deal making. By 2009, at the depth of the crisis, Asia had begun to take a bigger role; it claimed 25 percent of all global activities. To be sure, this rebalancing is in part a result of the sharp decline in PE activity in North America and Europe during the crisis. In 2010, with global deal flow picking up, Asia's share settled at about 17 percent. The stability of the higher share of global activity is a testimony to the resilience of Asia in the downturn. Asia is now a priority for many global firms, drawn by the positive macroeconomic environments of the largest economies of China and India, the restructuring potential of Japan and South Korea, and the freewheeling opportunities to be found in Southeast Asia. As shown in table 3 in the appendix, the Pearson correlation indicates that there is a positive association between GDP growth and the private equity activities. This confirms the argument that growing economies with low inflation tend to attract investors from all walks. According to the World Bank data (2014), in 2010 when the private equity activity was almost three times that of closed rival, Latin America, GDP soared, growing by 15 percent in Singapore, Japan (4 percent), China (10 percent), and India ( 8 percent) reflecting a growth across Asia. Appendix table 6 shows limited changes in the coefficients for GDP growth rate. The random effect model shows that GDP growth is significant at 5\% initially before including many variables. The positive significant influence is in line with the arguments of Gompers et al. (2008) who noted that increases in the real GDP growth lead to greater commitments to venture funds. However the result is inconsistent with Jeng and Wells (2000) who concluded that GDP growth is not statistically significant.

Gompers et al. (2008) pointed that, many business opportunities will emerge if there is an economic boom. More specifically, as shown in appendix table 3, there is a positive correlation between stock market value and GDP growth, implying that economic boom attracts excellent returns in the stock market and hence greater research and development expenditures may increase the demand for venture capital. However, a negative association between lending rates and private equity funding depicts that an increase in interest rates may also lead to a decrease in the supply of venture capital, as investment in loans is an alternative asset class to venture capital and private equity. As shown in appendix table 6, the lending rate is significantly, although fragile, but likely to be robust. This could be attributed to the fact that there was a variation of lending rates across the sample. That is, the mean was, 7.77 , while the maximum, minimum and standard deviation were 16, 1.6 and 3.8 respectively as shown in appendix table 2 .

It should be noted that, the deal flow in a given country does not only depend on macroeconomic but also so called environmental variables. Some of the environmental factors considered include, the investors' protection index, number of days enforcing a contract and start a business, the property 
rights index and disclosure index. The result indicates that, a strong legal environment is more likely to attract private equity. That is, there is a positive association between disclosure and investors protection (significant at $5 \%$ and robust) indices with PE. Likewise, private credit to GDP has a positive and significant influence to $\mathrm{PE}$. In the same manner, property right index, although likely to be robust has a positive coefficient but not significant. In addition, the more the number of days to enforce a contract in a country, the less likely it is to attract PE. This implies that, better legal systems place more emphasis on the use of debt to provide downside protection of investors' cash flow rights. Bottazzi et al. (2009) also demonstrate that, the optimal amount of debt increases in a better legal system up to a certain threshold and then decreases. Therefore, expansion stage venture capital or private equity, which relies on some debt should increase non-linearly in weaker legal systems.

The inclusion of taxation in the model also helps in assessing the impact in attracting the investors. The results show that, there is a negative association of corporation tax and PE is confirming the findings of Groh and Lichtenstein (2009). In addition, corporation tax is significant and robust, according to Leamer test. This implies that, a higher corporate tax rate should reduce venture capital activity to the extent that it reduces incentives to be self -employed and should have a larger impact on the effective tax burden of investors than the individual income tax (Kumar and Schuetze, 2007).

\section{Section 5: Conclusion}

Empirical studies have demonstrated that, venture capital and private equity influence, innovation, productivity and hence employment in an economy (Engel, 2002; Davis et al. 2008). The macroeconomic and environmental factors play a great role in enhancing the PE activities. While macroeconomic factors enhance the returns, the environmental or legal environment provide "public good" such as efficient court system and taxation. In particular, using panel data from 9 Asian countries spanning from 2004 to 2013, the paper tests whether financial market conditions, stock market performance, taxation and regulation are driving forces of PE activity. Using EBA, the results indicate that there are four variables that are robust. That is, corporation tax rate, GDP growth, disclosure index and investors protection. On the other hand, six variables are likely robust. These are, inflation ratio, stock market value, property right index, lending rate, legal costs and time in days to start a business. This implies that, fast growing economies, a well-developed stock market and robust legal system tend to attract PE. The study support Cumming and Johan (2007) who argued that a higher quality of a country legal system facilitates a more favourable legal environment to induce VCs to invest more often at home and less often abroad. In addition, the lower the corporate tax rate is, the more PE will flow into these emerging markets.

The results also indicate that the lending interest rate without the inclusion of other variables, significantly influence PE, but when the other regressors are added into the model, it is insignificant hence according to Sala-I-Martin, it is likely to be robust. A possible explanation for this result, which is in line with the outcome of the EBA, is that the level of interest rates has an ambiguous effect on PE, depending on the preponderance of supply-side or demand-side effects on PE. However, the inclusion of factors like corporate governance, research and development activities could go a step further in assessing what attract PE.

\section{Appendix}

Table 1. Definitions of the variables.

\begin{tabular}{|c|c|c|}
\hline Category of variables & Variables & Measurement \\
\hline \multirow{7}{*}{ Economic Activity } & Economic Growth & \%Change in GDP \\
\hline & Stock market value traded & Stock market value traded as \% of GDP \\
\hline & Interest rates & Short-term (3-months) interest rate in $\%$. \\
\hline & Lending/GDP & Commercial bank lending to private sector in $\%$ of GDP. \\
\hline & Inflation & Annual change of (harmonized) CPI in $\%$. \\
\hline & Corporation tax & Corporation tax rate in $\%$ \\
\hline & Strength of property rights Rule of law & Property rights index \\
\hline \multirow[t]{3}{*}{ Other indicators } & & Cost to enforce a contract recorded as a percentage of the claim, assumed to be \\
\hline & Cost of legal action & $\begin{array}{l}\text { equivalent to } 200 \% \text { of income per capita. Only official costs required by law are } \\
\text { recorded, including court and enforcement costs and average attorney fees where } \\
\text { the use of attorneys is mandatory or common }\end{array}$ \\
\hline & Disclosure index & The index ranges from 0 to 10 , with higher values indicating more disclosure \\
\hline
\end{tabular}

Table 2. Descriptive statistics

\begin{tabular}{|c|c|c|c|c|c|c|c|c|c|c|c|c|c|}
\hline & Vc_pe & $\mathrm{Ct}$ & Disc & Enfo.con & Gdp & Infl & Inv.pro & Legalcost & $\begin{array}{l}\text { Lending } \\
\text { rate }\end{array}$ & $\begin{array}{l}\text { Private } \\
\text { credit }\end{array}$ & $\begin{array}{l}\text { Property } \\
\text { right }\end{array}$ & $\begin{array}{l}\text { Time to } \\
\text { business }\end{array}$ & $\begin{array}{l}\text { Sto.market } \\
\text { value }\end{array}$ \\
\hline Mean & 4.48 & 45.41 & 7.61 & 34.78 & 6.20 & 5.33 & 6.04 & 28.60 & 7.77 & 112.93 & 6.51 & 16 & $1.11 \mathrm{E}+12$ \\
\hline Max & 21.40 & 81.2 & 10 & 46.00 & 15.20 & 22.67 & 9.30 & 39.60 & 16.00 & 330.78 & 10 & 15 & $6.23 \mathrm{E}+12$ \\
\hline Min & 0.017 & 23.20 & 2.00 & 21.00 & -5.50 & -5.99 & 1.70 & 11.10 & 1.60 & 36.39 & 3.00 & 3 & $4.61 \mathrm{E}+08$ \\
\hline $\begin{array}{l}\text { Std } \\
\text { dev }\end{array}$ & 5.89 & 15.29 & 2.93 & 6.47 & 3.90 & 5.01 & 2.10 & 9.71 & 3.81 & 80.11 & 2.28 & 11 & $1.68 \mathrm{E}+12$ \\
\hline obs & 80 & 80 & 80 & 80 & 80 & 80 & 80 & 80 & 80 & 80 & 80 & 80 & 80 \\
\hline
\end{tabular}


Table 3. Pearson Correlation.

\begin{tabular}{|c|c|c|c|c|c|c|c|c|c|c|c|c|c|}
\hline & Vc_pe & $\mathbf{C t}$ & Disc & Enfcon & Gdp & Infl & Inv.pro & Legalcost & Lendingrate & $\begin{array}{l}\text { Private } \\
\text { credit }\end{array}$ & $\begin{array}{l}\text { Property } \\
\text { right }\end{array}$ & $\begin{array}{l}\text { Time to } \\
\text { business }\end{array}$ & $\begin{array}{l}\text { Sto.market } \\
\text { value }\end{array}$ \\
\hline Vc_pe & 1.00 & & & & & & & & & & & & \\
\hline $\mathrm{Ct}$ & -0.698 & 1.00 & & & & & & & & & & & \\
\hline Disc & 0.259 & -0.108 & 1.00 & & & & & & & & & & \\
\hline Enfcon & -0.046 & 0.579 & -0.295 & 1.00 & & & & & & & & & \\
\hline Gdp & 0.229 & 0.248 & 0.117 & 0.119 & 1.00 & & & & & & & & \\
\hline Infl & -0.228 & -0.013 & -0.076 & 0.469 & 0.228 & 1.00 & & & & & & & \\
\hline Inv.pro & 0.038 & -0.346 & 0.648 & -0.608 & -0.126 & -0.463 & 1.00 & & & & & & \\
\hline Legalcost & -0.245 & -0.329 & -0.104 & -0.104 & -0.098 & 0.145 & 0.244 & 1.00 & & & & & \\
\hline Lending rate & -0.371 & -0.074 & -0.194 & 0.575 & 0.167 & 0.610 & -0.511 & 0.311 & 1.00 & & & & \\
\hline Privatecredit & 0.452 & 0.200 & 0.157 & -0.260 & -0.385 & -0.521 & 0.205 & -0.193 & -0.659 & 1.00 & & & \\
\hline $\begin{array}{l}\text { Time to } \\
\text { business }\end{array}$ & -0.054 & 0.049 & -0.592 & 0.172 & -0.138 & 0.257 & 0.640 & 0.050 & 0.222 & 0.201 & -0.108 & 1.00 & \\
\hline $\begin{array}{l}\text { Stock mark } \\
\text { value }\end{array}$ & 0.651 & 0.595 & 0.163 & 0.013 & 0.051 & -0.346 & 0.034 & -0.258 & -0.505 & 0.600 & -0.155 & 0.073 & 1.00 \\
\hline
\end{tabular}

Table 4. Breusch-Godfrey Serial Correlation LM Test:

\begin{tabular}{|c|c|c|c|c|}
\hline F-statistic & 1.248976 & \multicolumn{2}{|c|}{ Prob. F(2,49) } & 0.2958 \\
\hline Obs*R-squared & 3.104374 & \multicolumn{2}{|c|}{ Prob. Chi-Square(2) } & 0.2118 \\
\hline \multicolumn{5}{|l|}{ Test Equation: } \\
\hline \multicolumn{5}{|l|}{ Method: Least Squares } \\
\hline \multicolumn{5}{|l|}{ Date: 07/07/14 Time: $14: 58$} \\
\hline \multicolumn{5}{|l|}{ Sample: 179} \\
\hline \multicolumn{5}{|c|}{ Presample and interior missing value lagged residuals set to zero. } \\
\hline Variable & Coefficient & Std. Error & t-Statistic & Prob. \\
\hline $\mathrm{C}$ & 0.451686 & 4.786145 & 0.094374 & 0.9252 \\
\hline $\mathrm{Ct}$ & -0.006366 & 0.037686 & -0.168929 & 0.8665 \\
\hline Disclosure & 0.053636 & 0.192320 & 0.278888 & 0.7815 \\
\hline Enforcing_contracts_day & 0.019314 & 0.090608 & 0.213165 & 0.8321 \\
\hline Inflation & 0.015031 & 0.096283 & 0.156112 & 0.8766 \\
\hline Investors_protection & -0.115381 & 0.609830 & -0.189202 & 0.8507 \\
\hline Legalcost & 0.015513 & 0.052938 & 0.293035 & 0.7707 \\
\hline Lending_rate & -0.105650 & 0.252969 & -0.417642 & 0.6780 \\
\hline Privatecredit & -0.001234 & 0.009239 & -0.133517 & 0.8943 \\
\hline Propertyright & -0.012767 & 0.257056 & -0.049665 & 0.9606 \\
\hline Stockmarketvalue & $-2.47 \mathrm{E}-14$ & $3.36 \mathrm{E}-13$ & -0.073687 & 0.9416 \\
\hline Time_to_start_business & -0.000976 & 0.081242 & -0.012009 & 0.9905 \\
\hline $\operatorname{Resid}(-1)$ & 0.236543 & 0.152081 & 1.555377 & 0.1263 \\
\hline $\operatorname{Resid}(-2)$ & -0.070910 & 0.161818 & -0.438208 & 0.6632 \\
\hline R-squared & 0.048506 & \multicolumn{2}{|c|}{ Mean dependent var } & $-2.15 \mathrm{E}-15$ \\
\hline Adjusted R-squared & -0.223350 & \multicolumn{2}{|c|}{ S.D. dependent var } & 1.845830 \\
\hline S.E. of regression & 2.041583 & \multicolumn{2}{|c|}{ Akaike info criterion } & 4.467015 \\
\hline Sum squared resid & 204.2349 & \multicolumn{2}{|c|}{ Schwarz criterion } & 4.973003 \\
\hline Prob(F-statistic) & 0.999467 & & & \\
\hline
\end{tabular}

\footnotetext{
${ }^{2} \mathrm{VC} / \mathrm{PE}$ is venture capital/ private equity; CT is corporation tax rate; DISC is the disclosure index; ENFCON is time to enforce a contract; GDP is gross domestic product growth; INFL is inflation rate; INV.PRO is the investors' protection index; LEGALCOST is the cost of enforcing a contract; LENDING RATE; is the short term interest rate; PRIVATECREDIT is the private Credit to GDP; PROPERTY RIGHT is the property right index; TIME TO BUSINESS, is the duration in days to start a business and STO.MARKET VALUE is the value of stock market.
} 
Table 5. Heteroskedasticity Test: $A R C H$

\begin{tabular}{|c|c|c|c|c|}
\hline F-statistic & 0.373379 & Prob. $F(1,54)$ & & 0.5437 \\
\hline Obs*R-squared & 0.384549 & Prob. Chi-Square(1) & & 0.5352 \\
\hline \multicolumn{5}{|l|}{ Test Equation: } \\
\hline \multicolumn{5}{|c|}{ Dependent Variable: RESID ${ }^{\wedge} 2$} \\
\hline \multicolumn{5}{|c|}{ Method: Least Squares } \\
\hline \multicolumn{5}{|c|}{ Date: 07/07/14 Time: $14: 59$} \\
\hline \multicolumn{5}{|c|}{ Sample (adjusted): 279} \\
\hline \multicolumn{5}{|c|}{ Included observations: 56 after adjustments } \\
\hline Variable & Coefficient & Std. Error & $\mathrm{t}$-Statistic & Prob. \\
\hline $\mathrm{C}$ & 3.142157 & 0.883584 & 3.556149 & 0.0008 \\
\hline $\operatorname{RESID}^{\wedge} 2(-1)$ & 0.077892 & 0.127474 & 0.611048 & 0.5437 \\
\hline R-squared & 0.006867 & Mean dependent var & & 3.424976 \\
\hline Adjusted R-squared & -0.011524 & S.D. dependent var & & 5.600210 \\
\hline S.E. of regression & 5.632388 & Akaike info criterion & & 6.330005 \\
\hline Sum squared resid & 1713.085 & Schwarz criterion & & 6.402339 \\
\hline Log likelihood & -175.2401 & Hannan-Quinn criter. & & 6.358049 \\
\hline F-statistic & 0.373379 & Durbin-Watson stat & & 1.686183 \\
\hline Prob(F-statistic) & 0.543732 & & & \\
\hline
\end{tabular}

Table 6. Panel Data estimation using Random effect. Dependent Variable VC/PE, venture capital/ private equity and independent variables: VC/PE is; CT is corporation tax rate; DISC is the disclosure index; ENFCON is time to enforce a contract; GDP is gross domestic product growth; INFL is inflation rate; INV.PRO is the investors' protection index; LEGALCOST is the cost of enforcing a contract; LENDING RATE; is the short term interest rate; PRIVATECREDIT is the private Credit to GDP; PROPERTY RIGHT is the property right index; TIME TO BUSINESS, is the duration in days to start a business and STO.MARKET VALUE is the value of stock market.

\begin{tabular}{|c|c|c|c|c|c|c|c|c|c|}
\hline & & \multirow[b]{2}{*}{ Coefficient } & \multirow[b]{2}{*}{ AVG S.E } & \multirow[b]{2}{*}{ t. Statistics } & \multirow[b]{2}{*}{ P value } & \multicolumn{2}{|c|}{ Leamer test } & \multicolumn{2}{|l|}{ Sala-I-Martin EBA } \\
\hline & & & & & & $\begin{array}{l}\text { Lower } \\
\text { Bound }\end{array}$ & $\begin{array}{l}\text { Upper } \\
\text { Bound }\end{array}$ & CDFNonnormal & CDFnormal \\
\hline \multirow[t]{4}{*}{$\mathrm{X} 1$} & Gdp & 0.117 & 0.135 & 0.871 & 0.067 & -0.898 & 1.133 & 0.533 & 0.550 \\
\hline & $\mathrm{Ct}$ & -0.238 & 0.033 & -7.161 & 0.000 & -0.778 & 1.254 & 0.579 & 0.600 \\
\hline & Lending_rate & -0.826 & 0.214 & -3.844 & 0.000 & -1.842 & 0.19 & 0.801 & 0.204 \\
\hline & Infl & 0.201 & 0.166 & 1.203 & 0.233 & -0.815 & 1.217 & 0.564 & 0.580 \\
\hline \multirow[t]{5}{*}{$\mathrm{X} 2$} & Gdp & 0.336 & 0.146 & 2.296 & 0.025 & -0.180 & 0.336 & 0.616 & 0.632 \\
\hline & $\mathrm{Ct}$ & -0.202 & 0.033 & -6.028 & 0.000 & -0.314 & 0.202 & 0.566 & 0.580 \\
\hline & Lending rate & -0.348 & 0.257 & -1.354 & 0.180 & -0.864 & -0.348 & 0.645 & 0.364 \\
\hline & Infl & 0.111 & 0.159 & 0.696 & 0.488 & -0.405 & 0.111 & 0.530 & 0.544 \\
\hline & Private credit & 0.028 & 0.009 & 3.001 & 0.003 & -0.488 & 0.028 & 0.500 & 0.511 \\
\hline \multirow[t]{6}{*}{$\mathrm{X} 3$} & Gdp & 0.245 & 0.143 & 1.710 & 0.092 & 0.245 & 0.735 & 0.582 & 0.600 \\
\hline & $\mathrm{Ct}$ & -0.221 & 0.032 & -6.776 & 0.000 & -0.269 & 0.711 & 0.572 & 0.587 \\
\hline & Lending rate & -0.277 & 0.245 & 1.127 & 0.264 & -0.767 & 0.213 & 0.619 & 0.391 \\
\hline & Infl & 0.073 & 0.152 & 0.479 & 0.633 & -0.417 & 0.563 & 0.516 & 0.529 \\
\hline & Private credit & 0.025 & 0.009 & 2734 & 0.008 & -0.465 & 0.515 & 0.500 & 0.510 \\
\hline & Disc & 0.445 & 0.163 & 2.723 & 0.009 & -0.045 & 0.935 & 0.655 & 0.672 \\
\hline \multirow[t]{7}{*}{$\mathrm{X} 4$} & Gdp & -0.003 & 0.090 & -0.029 & 0.977 & -0.317 & 0.311 & 0.514 & 0.498 \\
\hline & $\mathrm{Ct}$ & -0.089 & 0.024 & -3.692 & 0.000 & -0.225 & 0.403 & 0.522 & 0.535 \\
\hline & Lending rate & -0.200 & 0.149 & -1.339 & 0.185 & -0.514 & 0.114 & 0.589 & 0.421 \\
\hline & Infl & 0.057 & 0.0923 & 0.620 & 0.537 & -0.257 & 0.371 & 0.509 & 0.523 \\
\hline & Private credit & -0.018 & 0.007 & -2.571 & 0.127 & -0.332 & 0.296 & 0.519 & 0.493 \\
\hline & Disc & 0.326 & 0.098 & 3.264 & 0.002 & 0.012 & 0.64 & 0.612 & 0.628 \\
\hline & Sto.market value & $3.03 \mathrm{E}-12$ & $3.17 \mathrm{E}-13$ & 9.557 & 0.000 & -0.314 & 0.314 & 0.508 & 0.522 \\
\hline
\end{tabular}

Table 6. Continued.

\begin{tabular}{|c|c|c|c|c|c|c|c|c|c|}
\hline & & \multirow[b]{2}{*}{ Coefficient } & \multirow[b]{2}{*}{ AVG S.E } & \multirow[b]{2}{*}{ t. Statistics } & \multirow[b]{2}{*}{ P value } & \multicolumn{2}{|c|}{ Leamer test } & \multicolumn{2}{|c|}{ Sala-I-Martin EBA test } \\
\hline & & & & & & $\begin{array}{l}\text { Lower } \\
\text { Bound }\end{array}$ & $\begin{array}{l}\text { Upper } \\
\text { Bound }\end{array}$ & CDFNonnormal & CDFnormal \\
\hline \multicolumn{10}{|l|}{$\mathrm{X} 5$} \\
\hline & Gdp & -0.012 & 0.091 & -0.132 & 0.895 & -0.292 & 0.268 & 0.517 & 0.495 \\
\hline & $\mathrm{Ct}$ & -0.097 & 0.025 & -3.802 & 0.000 & -0.183 & 0.377 & 0.525 & 0.539 \\
\hline & Lending_rate & -0.185 & 0.151 & -1.230 & 0.224 & -0.466 & 0.095 & 0.584 & 0.427 \\
\hline & Infl & 0.056 & 0.093 & 0.606 & 0.546 & -0.224 & 0.336 & 0.509 & 0.522 \\
\hline & Privatecredit & -0.019 & 0.007 & -2.659 & 0.010 & -0.299 & 0.261 & 0.520 & 0.492 \\
\hline & Disc & 0.293 & 0.105 & 2.785 & 0.007 & 0.0128 & 0.573 & 0.599 & 0.615 \\
\hline & Sto.marketvalue & $3.08 \mathrm{E}-12$ & $3.22 \mathrm{E}-13$ & 9.546 & 0.000 & -0.280 & 0.28 & 0.504 & 0.517 \\
\hline & Propertyright & 0.149 & 0.148 & 1.011 & 0.316 & -0.412 & 0.429 & 0.545 & 0.559 \\
\hline \multirow[t]{2}{*}{$\mathrm{X} 6$} & Gdp & -0.035 & 0.093 & -0.377 & 0.707 & -0.596 & 0.525 & 0.526 & 0.486 \\
\hline & $\mathrm{Ct}$ & -0.222 & 0.037 & -5.962 & 0.000 & -0.339 & 0.782 & 0.573 & 0.588 \\
\hline
\end{tabular}




\begin{tabular}{|c|c|c|c|c|c|c|c|c|}
\hline & \multirow[b]{2}{*}{ Coefficient } & \multirow[b]{2}{*}{ AVG S.E } & \multirow[b]{2}{*}{ t. Statistics } & \multirow[b]{2}{*}{$P$ value } & \multicolumn{2}{|c|}{ Leamer test } & \multicolumn{2}{|c|}{ Sala-I-Martin EBA test } \\
\hline & & & & & $\begin{array}{l}\text { Lower } \\
\text { Bound }\end{array}$ & $\begin{array}{l}\text { Upper } \\
\text { Bound }\end{array}$ & CDFNonnormal & CDFnormal \\
\hline Lending_rate & 0.068 & 0.250 & 0.273 & 0.785 & -0.493 & 0.628 & 0.514 & 0.527 \\
\hline Infl & -0.003 & 0.097 & -0.036 & 0.970 & -0.564 & 0.557 & 0.514 & 0.499 \\
\hline Privatecredit & -0.024 & 0.009 & -2.556 & 0.013 & -0.585 & 0.536 & 0.522 & 0.490 \\
\hline Disc & 0.497 & 0.194 & 2.560 & 0.013 & -0.064 & 1.057 & 0.673 & 0.690 \\
\hline Sto.marketvalue & $2.55 \mathrm{E}-12$ & $3.35 \mathrm{E}-13$ & 7.611 & 0.000 & -0.560 & 0.56 & 0.507 & 0.520 \\
\hline Propertyright & 0.425 & 0.254 & 1.671 & 0.100 & -0.986 & 0.135 & 0.673 & 0.335 \\
\hline Legalcost & 0.038 & 0.053 & 0.715 & 0.477 & -0.523 & 0.598 & 0.502 & 0.515 \\
\hline Enfcon & -0.307 & 0.091 & -3.349 & 0.001 & -0.868 & 0.253 & 0.630 & 0.379 \\
\hline Inv.pro & 0.625 & 0.602 & 1.036 & 0.304 & 0.064 & 1.185 & 0.716 & 0.734 \\
\hline Time to business & 0.142 & 0.080 & 1.782 & 0.080 & -0.419 & 0.702 & 0.543 & 0.556 \\
\hline Adjusted R squared & $88 \%$ & & & & & & & \\
\hline F-statistic & $40.27924 * * *$ & & & & & & & \\
\hline Durbin-Watson stat & 1.952231 & & & & & & & \\
\hline
\end{tabular}

\section{References}

[1] Belke, A., R. Fehn, and Foster, N. (2003), "Does Venture Capital Investment Spur Employment Growth?," CESIFO Working Paper 930.

[2] Bonini, S. and Alkan, S. (2009), "The Macro and Political Determinants of Venture Capital Investments around the World," Available at SSRN:http://ssrn.com/abstract=945312. Accessed on 01/07/2014

[3] Bottazzi, Laura, Marco Da Rin, and Thomas . H. F. (2009). What is the role of legal systems in financial intermediation? Theory and evidence. Journal of Financial Intermediation 18, pp. 559-598.

[4] Bruce, D. (2000) "'Effects of the United States Tax System on Transition into Self Employment," Labour Economics, 7. pp. 545-574.

[5] Bruce, D. (2002) 'Taxes and Entrepreneurial Endurance. Evidence from Self Employment," National Tax Journal, 55.pp 5-24.

[6] Cullen, J. B. and Gordon, R. H. (2002 'Taxes and Entrepreneurial Activity." Theory and Evidence from the US. NBER Working paper 9015.

[7] Cumming, D. J. and Johan, S. A. (2007). Regulatory Harmonization and the Development of Private Equity Markets. Journal of Banking and Finance, 31, pp. $3218-$ 3250 .

[8] Cumming, D. D. Schmidt, and U. Walz (2010), "Legality and Venture Governance around the World," Journal of Business Venturing, 25, pp. 54-72.

[9] Davis, S. J., John H. R. S., Jarmin, J. L, and Javier, M. (2008). Private equity and employment. Working Paper no. 08-07, (March), Centre for Economic Studies, Bureau of the Census, Washington, D.C.

[10] Desai, M., P. Gompers, and Lerner, J. (2006), "Institutions and Entrepreneurial Firm Dynamics: Evidence from Europe," Harvard NOM Research Paper 03-59.

[11] Dougherty, C. (2007). Introduction to econometrics: Oxford University Press, USA.

[12] Emerging market private Equity Association, EMPEA (2014) Data Insights Report. Available

[http://empea.org/research/data-and-statistics/empea-datainsights-q1-2014/] accessed on 10/07/2014.

[13] Engel, D. (2002). The Impact of Venture Capital in Firm Growth: An Empirical Question. ZEW Discussion Paper, 0202: 30. Available at SSRN: http://ssrn.com/abstract=319322. Accessed on 10/07/2014.

[14] Ernst and Young (2014) Asia Pacific Private Equity Outlook, 2014. Available http://www.ey.com/GL/en/Industries/Private-Equity/AsiaPacific-private-equity-outlook-2014. Accessed on 14/07/2014.

[15] Friedman, F.B. and Grose, C. (2006). Promoting Access to Primary Equity Markets: A Legal and Regulatory Approach. World Bank Policy Research Working Paper 3892.

[16] Gompers, P., Kovner, A., Lerner, J. and Scharfstein, D. (2008). Venture capital investment cycles: the impact of public markets. Journal of Financial Economics. 87, pp. 1-23.

[17] Groh, A. P and Liechtenstein, H. (2009a) International Allocation Determinants of Institutional Investment in Venture Capital and Private Equity Limited Partnerships," IESE Business School, Working paper 726.

[18] Groh, A. P and Liechtenstein, H. (2009b) How attractive is Central Eastern European for Risk Capital Investors?," Journal of International Money and Finance, Forthcoming.

[19] Jeng, L. A. and Wells. C. P. (2000). The determinants of venture capital funding: Evidence across countries. Journal of Corporate Finance 6 (September), no.3: 241-289.

[20] Karl, Terry Lynn, 1997. The Paradox of Plenty: Oil Booms and Petro-States. Berkeley, University of California Press.

[21] Kortum, S. and J. Lerner (2000), "Assessing the Contribution of Venture Capital to Innovation," Rand Journal Economics, 31, pp. 674-692.

[22] Kumar, V. and Orleck. S. (2002) Why does private equity vary across countries and time? DukeJournal of Economics 14 (Spring).

[23] Leamer, E.E. (1983), "Let's take the Con Out of Econometrics", American Economic Review 73, 3, 31-43.

[24] Leamer, E.E. (1985), "Sensitivity Analysis Would Help", American Economic Review 75, 308-313.

[25] Levine, R. and D. Renelt (1992), "A sensitivity analysis of cross-country growth regressions", American Economic Association 82, 4, pp. 942-963. 
[26] Makhene, M. (2009). Alternative Growth: The Impact of Emerging Market Private Equity on Economic Development. Neumann. Business Review, Spring ,2009, pp. 17-47.

[27] Sachs, J. D. (2001). “Tropical Underdevelopment.” prepared for Economic History Association Annual Meeting, September 2000 and CID Working Paper No. 57, December 2000 available at http://www.cid.harvard.edu/cidwp/057.htm accessed on 09/07/2014.

[28] Sala-i-Martin, (1997), "I just ran two million regressions", American Economic Association 87, 2, pp. 178-183.
[29] Schertler, A. (2003), "Driving Forces of Venture Capital Investments in Europe: A Dynamic Panel Data Analysis, European Integration, Financial Systems and Corporate Performance," United Nations University (EIFC), Working Paper 03-27.

[30] Sturm, J. E. and J. de Haan (2005). "Determinants of longterm growth: New results applying robust estimation and extreme bounds analysis," Empirical Economics 30,3, pp. 597-617.

[31] World Bank Data (2014) Economic Indicators. Available at. http://data.worldbank.org/indicator accessed on 10/07/2014 